\title{
The Role of E-government and M-government in Shaping Jakarta to be a Smart City
}

\author{
Lya Anggraini \\ Master Candidate, Public Administration, Faculty of \\ Administrative Studies, Universitas Indonesia \\ Jakarta, Indonesia \\ lya.anggraini@gmail.com \\ Muslim Bachtiar \\ Secretary, Tanjung Duren Urban Village Government \\ Office, \\ Jakarta, Indonesia \\ muslim.bachtiar@gmail.com
}

\author{
Sri Lestari \\ Master Candidate, Public Administration, Faculty of \\ Administrative Studies, Universitas Indonesia \\ Jakarta, Indonesia \\ elsrie@yahoo.com \\ Erwan Halil \\ Researcher, LP3ES (Institute for Social and Economic \\ Research, Education, and Information), \\ Jakarta, Indonesia \\ erwanhali1@gmail.com
}

\begin{abstract}
The government of Indonesia has shown its commitment to implement information, communication and technology (ICT) based governance with the launching of 100 Smart City Action by the Ministry of Communication and Informatics. As the nation's capital, Jakarta becomes example of ICT based governance. After implementing web based governance (e-government) in all level of its work units, the provincial government of Jakarta launched mobile phone applications (m-government). This paper reviews the development of e-government and m-government and its implementation in the provincial government of Jakarta. Interactions between actors involved in Jakarta's ICT based governance are studied and its institutional perspective reviewed. The paper questions how ICT based governance (both egovernment and m-government) has changed working attitude of government officials, how the presence of mobile phone applications (mobile apps) changes the way citizen and the government interact. We argue that e-government has enhanced the effectiveness of public administration and inter-governments program implementations. Moreover, we argue that citizen will use mobile application to interact with the government if it satisfies his/her sense of self identify, enable him/her to further pursue his/her own interest and if the respond from the government meet their expectation. In this research, we found that government should adapt to the changes of demographic condition of their citizen. In terms of government and citizen interaction, senior citizen and conservative community prefer traditional real life interaction (communication in person) while young citizen and more modern community prefer online interaction (communication through internet based channel). To maximize ICT based interaction between government and citizen, we argue that regular trainings on internet based mobile applications for elder citizens (who usually hold strategic positions and represent community in interaction with government) will guarantee the sustainable use of the application.
\end{abstract}

Keywords- Smart City, E-Government, M-Government, Citizen participation, citizen and government interaction

\section{INTRODUCTION}

The government of Jakarta needs innovative public services to manage the city with more than ten million population. Problems become more complex in relations to housing, city planning, transportation, and other urban aspects. Citizens nowadays are more educated, more critical, and more openminded. They actively participate in advocating issues in responding to the government policies. To adapt to the changes of citizen's character, the government needs to develop innovative and creative mechanism as a channel for public participation. A good mechanism will build closer relationship between government and its citizen when developing policies, implementing programs, and the delivery of public services. Information Communication Technology (ICT) based public administration such as e-government and m-government will serve these purposes [3]. Therefore, the city government should be able to think beyond on how to make full use of the available ICT for public participation, delivering public services, and inter-agency communication [13].

The provincial government of Jakarta in its midterm plan for the period of 2013-2017 stated its mission to create welfare in the society, to improve its global competitiveness, by building facilities that will enhance innovative economic growth by respecting local cultures. The availability of internet infrastructure in Jakarta has enabled the government to provide internet based information on local development and public services. Mobile phone based application has been developed to build an online channel for public aspiration for the provincial government to respond. All levels of the government from the provincial, municipal to sub district level have been equipped with internet protocol to support city's management: finance, vehicle tax, ground water tax, human resource, asset management, procurement, and population information. 


\section{METHOD}

The design of this research was based on the constructivism paradigm to understand the two ways communication between the citizen and the government in Jakarta using internet based mobile phone application as a modern way of public service administration. By using mix quantitative and qualitative method, the research gained insight of different perspective from internet users and public servants as actors, the mobile application and the information system as the interaction, and the mechanism from the urban village level to the city office level as the institutions.

The research team is divided into two team: the first team consist of six enumerators led by a coordinator who surveyed 100 residents of provincial government of Jakarta (respondents were citizen of 5 cities or towns that make up a DKI Jakarta Province: Central, North, West, South, and East Jakarta). The target of the survey was focused to youth groups to understand future trends. The purposive sampling aims to find typical, extreme, critical, and sensitive cases of issues in Jakarta related to e-government and m-government. The data was tabulated and the analyzed report was passed to the second team that focuses on the qualitative part of the research. Further, a semi standard interview was developed targeting government officials in charge of managing incoming of information and responding to the complaints, as part of the triangulation process. The sampling for the interview was purposive, focusing on cities and urban village governments with the highest delay in response red zone and direction from the Governor of Jakarta namely West Jakarta City, North Jakarta City, and Central Jakarta City [12]

\section{RESULT AND DISCUSSION}

\section{A. The Need of Innovation in Public Services}

An online survey revealed that Jakarta citizen concerned that democracy was not well implemented as a result of policies related to religion $(37,6 \%)$, tribal and ethnicity $(28,4 \%)$, education $(18,3 \%)$, and the management of natural resource $(15,6 \%)$.

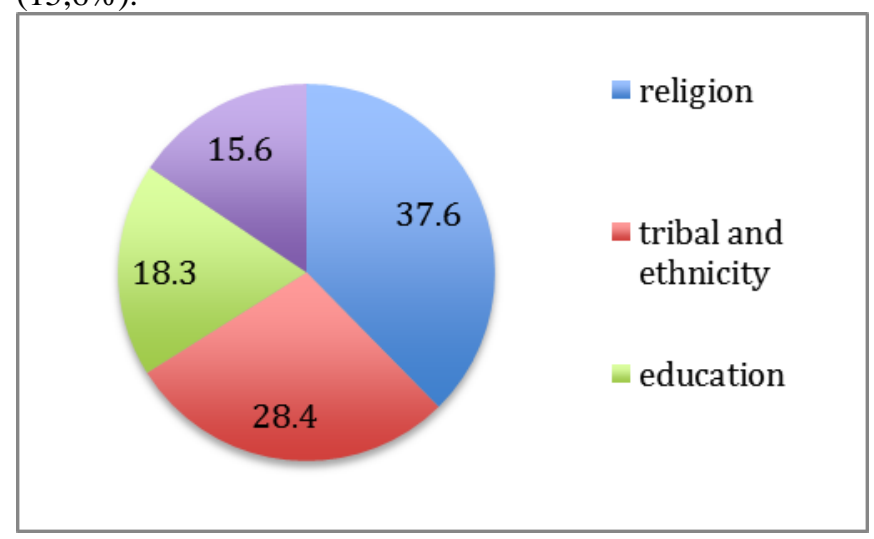

Figure 1. Policy topics discussed on-line (LP3ES, 2017)

Usually conflict will arise when discussion of a certain topic escalates into dispute that attract crowd that later get involved in the dispute. To solve the dispute, the Jakarta people uphold local wisdom in the form of musyawarah (consensus in decision making) and mabudiyah (politics based on the blessing of God, that later become slogan used by the organization Gerakan Pemuda Kebangkitan Bangsa/Garda Bangsa). Respondents think these local wisdoms have contributed to the development of democracy and peace. Engaging public in public administration does not come easy. Youth nowadays are less interested in social political movement within complex organizational structure. More and more groups of common interest based on hobbies are founded, some are doing positive activities such as sport and photography club, some others are negative like gangs or bike riders club that get together for criminal intention. The presence of youth organization in Jakarta are still dominated by internal campus organization $(33,3 \%)$, community groups $(24,2 \%)$, religious based organization $(17,2 \%)$, ethnic based groups $(13,1 \%)$, extension of political parties $(9,1 \%)$ and tribal based groups (3\%).

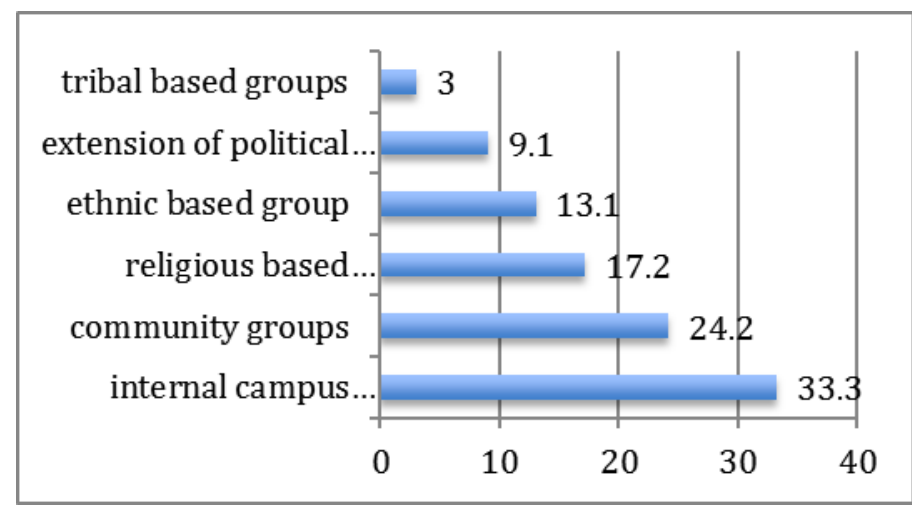

Figure 2. Youth organization in Jakarta (LP3ES, 2017)

According to the survey, most of the organizations were local based $(66,7 \%)$. More than half of the organizations that exists today $(58,6 \%)$ were founded in post 1998 reformations era, others were founded in the New Order Era between 1967 until 1998 (30,3\%). Based on their activities, youth organizations implement their program in collaboration with the government $(21,7 \%)$, non-government organization $(17,7 \%)$, education institution including universities $(17,1 \%)$, political organization $(11,4 \%)$, religious institution $(10,3 \%)$, youth organization including student unions $(6,9 \%)$ and private sector $(6,3 \%)$. 


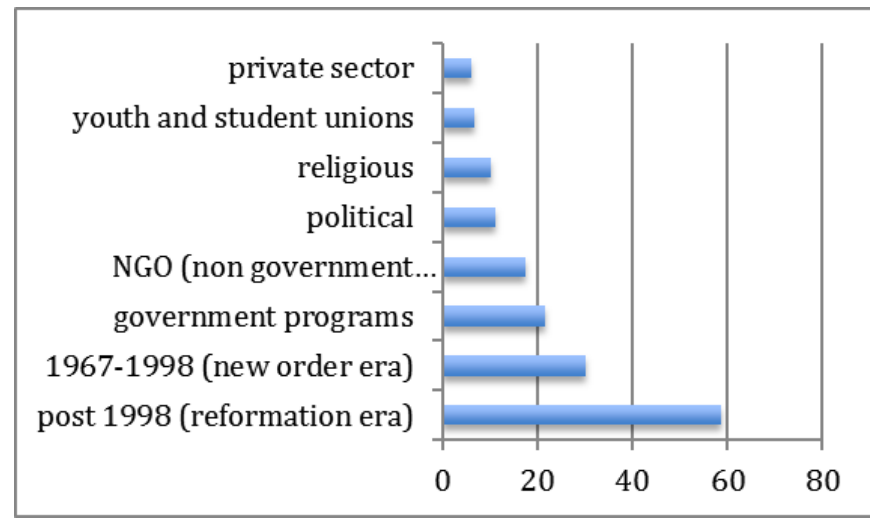

Figure 3. Youth organizations based on their establishment era and collaborators (LP3ES, 2017)

Youth organizations in Jakarta are critical towards how the government deliver their public services to the citizen. They have identified that $36,4 \%$ of government policies have created friction in the society. The policies that have the possibility to create conflict are related to doctrines of religious believes $(23,8 \%)$, policies on forestry and tenure $(21,4 \%)$, local regulations that are religious sensitive $(19 \%)$, education policies $(9,5 \%)$, prohibition to gather $(7,1 \%)$, and policies on labour $(7,1 \%)$.

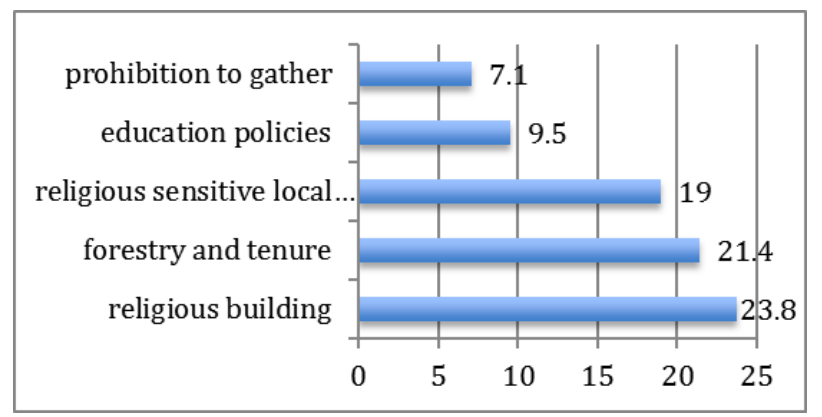

Figure 4. Government policies leading to conflict (LP3ES, 2017)

Further conflict can be driven from the following media, in order of conflict possibility: Facebook newsfeed $(15,2 \%)$, Online Media (14,6\%), Whatsapp (13,5\%), Twitter (12,9\%), leaflet $(9,5 \%)$, and printed paper $(7,7 \%)$. Youth considers that conflict is driven by hoax $(39,4 \%)$, hate speech $(20,6 \%)$, influence of buzzer $(19,4 \%)$, and bullying by individual and groups $(18,9 \%)$. Youth thinks that their organization can prevent the negative side of media by providing the right information to its members $(45,9 \%)$, and clarify information to the source to check if the news is correct $(26,7 \%)$.

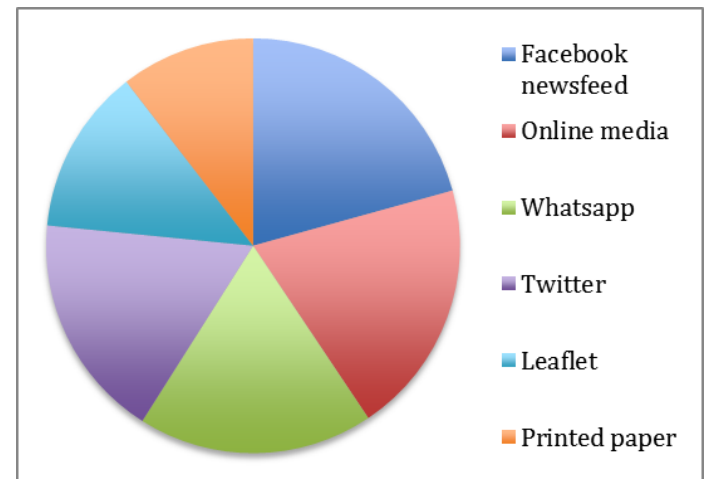

Figure 5. Social media that can foster conflict (LP3ES, 2017)

When disputes arise in the communities due to bad policies from the government, these youth organizations identifies that community groups $(28,7 \%)$ plays a role in mediating the conflicts. As the friction becomes greater that escalate into violence, the police/military $(17,5 \%)$ will be deployed to reduce the conflict keep the situation in order. Some youth think the executive $(13,8 \%)$ can have greater role in reducing the tension aroused by horizontal conflict in the future.

\section{B. The Growing Diffusion of Internet}

The growth of m-government in Indonesia is promising. A survey conducted by APJII (Association of Indonesian Internet Providers) in 2014 found a significant rise of internet use in Indonesia in the last 9 years from $7.8 \%$ in 2005 to 34.9 $\%$ in 2014. Internet diffusion in the capital city of Jakarta has reached $56 \%$ in 2014, which are mostly accessed from mobile phone $(85 \%)$, followed by laptop or notebook $(32 \%)$, personal computer (14\%) and tablet (13\%) [1].

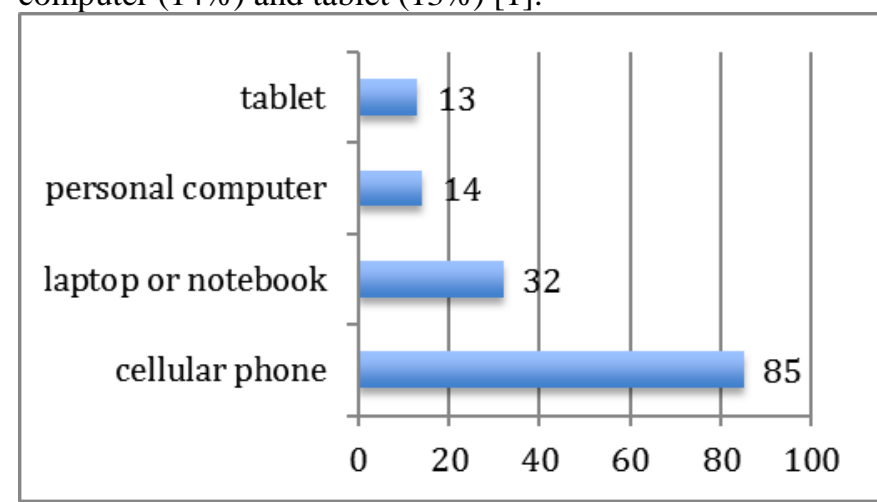

Figure 6. Gadget used to access the Internet (APJII, 2014)

In Indonesia, smart phones are widely used in Java and Bali island $(92 \%)$ followed by Papua, Maluku and Nusa Tenggara $(88 \%)$ and Kalimantan (80\%) [1]. The popular use of cellular phone to access internet, especially in the eastern part of Indonesia, which located far away from the central government in Java, is quite surprising. Infrastructures in the eastern provinces of Indonesia has long been known as less developed compared to the western part. 


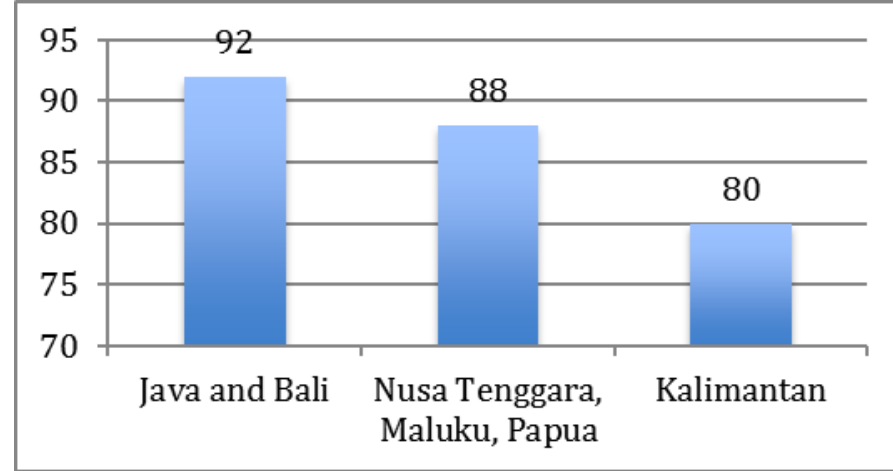

Figure 7. Use of Smart Phones in Indonesia (APJII, 2014)

In the context of democracy building in Jakarta Province, another survey have found that traditional media such as printed media and television were considered more effective in the education of politics and peace building[8]. Half of youth consider that television is an effective media to promote nation development and peace $(51,1 \%)$. Moreover, contrary to the contemporary belief that internet has taken over aired broadcast and printed media, the survey found that traditional printed news are still considered effective in contributing to the development of democracy and peace $(53,5 \%)$, followed by other traditional printed media i.e. leaflet $(46,5 \%)$, campus media $(46,5 \%)$, radio $(41,4 \%)$, twitter $(38,4 \%)$, and media campaign $(38,4 \%)$

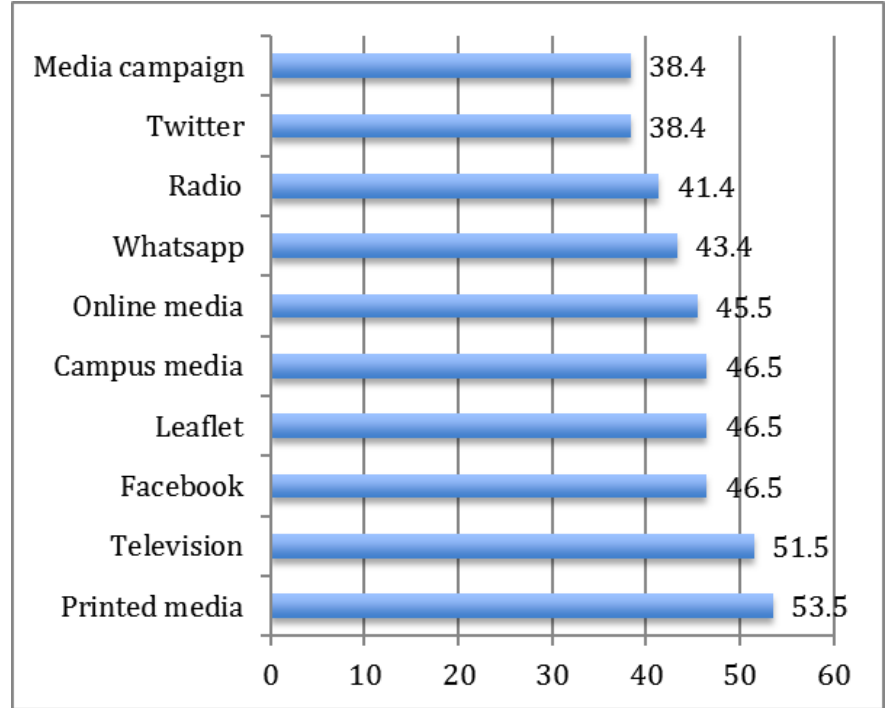

Figure 8. Effective media for building of democracies (LP3ES, 2017)

Those types of media are effective to support democracy and peace when their content are non-provocative $(25,2 \%)$, nonpartisan $(20,4 \%)$, uphold humanitarian value $(16,3 \%)$, and does not exploit conflict $(14,3 \%)$. When the media contains the opposite values of what were mentioned, values that are needed for a media in order to become agent of development and peace, youth consider that media will become a source of conflict $(66,7 \%)$.

\section{Government Policies}

E-government is intended for internal public administration accountability, a digital literacy community and knowledgeable informed citizen will improve external public administration accountability[9]. Government's effort to implement e-government and digital literacy community started with the Presidential Instruction No. 6/2001 on Telematics (telecommunication, media, and information) to support good governance and speed up democratization. Legal development supporting e-government continued with the Presidential Instruction No. 3/2003 on the National Policy and Strategy in the Development of E-Government. The instruction formed a legal basis for the ministry of communication and informatics as the coordinator of all government institution to foster the development of eleadership, the building of the information network infrastructure, information management, creating the business environment for e-government, and enhancing the capacity of the community and human resource. The Ministry of communication and informatics then issued a Decree No. $55 / 2003$ on the Development of the Government Infrastructure Portal. The ministry of communication and informatics has launched a 100 Smart City Action in mid 2017. The smart city is a vision to integrate information and communication technology in city management [9].

In the sub national level, the Provincial government of Jakarta developed its Midterm Plan for 2013-2017 that stated its commitment to "transparency", a condition where a right, clear, and sincere information will be provided to the citizen of Jakarta and guarantee their participation in development, and "good governance", that uphold the principles of participation, transparency, accountability, efficiency, and justice. The commitment is strengthened with a legal basis under the Jakarta Provincial Regulation Number 2/2013. Jakarta, as the capital of the nation, positions itself as the center of knowledge, technology and intellectualism.

\section{Implementation of E-Government}

The Association of Indonesian Municipalities (APEKSI) reminded that ICT is just a helping tool, hence too many apps are considered unnecessary. Aside from ICT based administration, the government should focus its attention to understand the needs of their citizen. According to a study that analysed sub national governments websites to see the impact of ICT based public services implemented by the sub national government in Jakarta, Bengkulu, Jambi, and Bangka Belitung, e-service score for provincial government of Jakarta's website (www.jakarta.go.id) was very low: $24.2 \%$. E-service scores for each municipal (kotamadya) in Jakarta are as follow: Central Jakarta municipal (pusat.jakarta.go.id) scored 25.6\%, South Jakarta municipal (selatan.jakarta.go.id) scored $12.7 \%$, East Jakarta municipal (timur.jakarta.go.id) scored $5.6 \%$. The low scored that Jakarta received was due to lack of policies and human resource to manage the ICT, and the preference for direct communication in person because of the geographical condition, which make it easier to reach places for direct interaction [5]. 
In recent years there have been a lot of progress in ICT based public administration. Ministries and government agencies have developed their management system for internal purposes and for the delivery of public services, both in egovernment and m-government[14]. Most of the ministries and government agencies in national, provincial and local level have implemented ICT based application for staff attendance record, procurement, budgeting, human resource, and whistleblower mechanism. Ministry of religious affairs has developed SMART application for Hajj management; ministry of environment and forestry has implemented WebGIS; ministry of women empowerment and child protection has Simfoni (Online Information System for Women and Child Protection); ministry of public works and public housing has various ICT based system such as information system for water resource (SISDA) for dams and rivers and housing support; ministry of transport has developed Moovit, ICT based public transportation routes; ministry of cooperatives and small and medium enterprise (SME) has early warning system for SME; ministry of energy and mineral resources has some ICT based applications such as One Map; ministry of communication and informatics has developed online health clinique; ministry of defense has Finisher; ministry of marine affairs and fisheries has Aid for Fish Catching application; ministry of trade has Online Information for Company Services; the national police has various ICT based application such as Intelligent Traffic Analysis (Intas and Pintas; the national agency for creative economy has digital and game developer; the national agency for labour placement and protection has ICT based job application mechanism; and the presidential office has LAPOR!, a reporting mechanism for public.

\section{E. The Implementation of E-Government and M-Government in Jakarta Province}

A team of researchers conducted interviews to urban villages and municipal government officials to study m-government implementation. Urban villages and municipals were selected based on the highest delay in responding complaints via the Qlue Apps as reported by Kompas newspaper [10], one of the largest printed media in Indonesia. Purposively, the samples of this research are urban villages and city offices located in Central Jakarta City, West Jakarta City, and North Jakarta City, all of which were considered as the "red zone". The interview questions were based on the analysis of previous surveys to 100 respondents and secondary information about the implementation of e-government and m-government in the Province of Jakarta.

The government officials from the municipal level to the village urban level are well informed about the Jakarta provincial government's midterm policies and programs for 2013-2017. Good leadership is evident in the West Jakarta municipal. Every Tuesday, the mayor gathers head of district and sub district or urban village for meeting and for monitoring the program implementation, restating his vision, mission, and programs for West Jakarta municipal so that all the districts and sub districts leaders have the same perception and are able to implement them effectively. This regular meeting becomes a forum to discuss challenges that the head of districts and sub districts were facing and to find solutions to their problems. The vice mayor will take charge and lead the meeting in the mayor's absence. This practice is effective to build confidence of all the lower level leaders to achieve difficult programs and enable them to delegate jobs effectively. The staffs were given clear job description and were well prepared to respond quickly to incoming complaints. At the urban village level, e-government and mgovernment have contributed to improved two ways communication and job delegation. The staff's salaries and allowances are more than adequate to make them work hard for the city.

We found that the "red zone" in the three municipals (Central Jakarta, West Jakarta, and North Jakarta) was due to the high participation of very critical citizens who made report of complaints about the conditions of public facilities and services. The city officials have responded complaints filed by citizens through Qlue apps, but the same complaints for the same condition of facilities were sometimes reported again by the same person, or by other persons. Complaints received are always reported to the mayor in the city's coordination meeting. The citizens of West Jakarta and North Jakarta municipal were highly critical, but Central Jakarta citizen were not. This could be due to the different demographic characteristic between the Central Jakarta and other two municipals. The former's citizens were not as comfortable with new ICT as the latter's citizens.

Complaints that were reported through Qlue apps varied from religious intolerance action by certain religious based organization (i.e request to pull down religious intolerance flag), threat to security and neighborhood stability caused by ethnic and religious based organization (i.e request to demolish headquarters of Forum Betawi Rempog). Complaints from citizens reflected complex problems that municipals were facing. It took long process to solve problems or incidents that happened within mixed populations of multicultural and multi religions. The municipals sometimes have to involve religious leaders, military, the police and their own civilian security force (Satuan Polisi Pamong raja/satpol pp) to solve them.

The provincial government's efforts to transform the capital of the nation into smart city face tremendous challenges that often leading to conflicts as a result of land acquisition process i.e the development of Child Friendly Outdoor Public Space (Ruang Publik Terbuka Ramah Anak/RPTRA), reorganization of public spaces and properties i.e eviction of illegal street vendors that conduct business along the public sidewalks or other public properties. The current leadership implements reward and punishment for the civil servants intended to make them more responsive to the citizen's complaints, however in recent months the sanctioning scheme becomes just a lip service to satisfy his constituents because unresponsive city's officials do not get any sanction. The red zone status in the Qlue apps does not effect job security of the head of district or sub district [2]. 
Contrary to the conclusion made by the Association of Indonesian Municipalities (APEKSI) that suggested conventional method of citizen and government interaction is more preferable, the municipals civil servants found that ICT has contributed to more efficient city management as it facilitates the municipal to govern high density population in large area. A head of urban village is in charge of an area of 50 hectares occupied by approximately $100-1000$ people. The width of area and the number of population pose a complex challenge for direct communication in person, therefore citizen and government interaction via social media or mobile application (for example Qlue) becomes the solution to connect both parties for two way communication; the government can respond to citizen immediately and at the same time kept itself well informed of the most current situation inside its territory.

As opposed to the research findings about the low score of Jakarta's (along with other provinces such as Bengkulu, Jambi, and Bangka Belitung) e-government implementation, where the use of ICT based services was only up to $25.6 \%$ [5], the municipal's officials explained that the use of ICT based apps in provincial government of Jakarta is intensive. One of the ICT based apps is e-pegawai. This app provides each government official a password protected personal account where they can store their digital files that they work on. The files can be stored as long as they work there, since they started their employment within the government until they retire. Staff attendances are recorded online for accurate monthly reporting in e-kinerja. The provincial program budgets are monitored within e-budgeting where expenses from the lowest level of government unit are tabulated to make up a whole office budget that become the basis a longterm provincial government budget design. Sub district office can download and input their records in an application called budget implementation document (Dokumen Pelaksanaan Anggaran/DPA), then put it in office bulletin board for transparency and accountability to the sub district citizen to see. Civil servants at all Jakarta government level receive training on ICT and its apps and its standard operational procedure to achieve objective of government responsiveness. In the sub district level, every morning at 8 am the head of sub district, his/her deputy and head of office section discuss incoming reports which they list according to priority order to decide which ones will be responded immediately and which ones they can delegate to their subordinate.

Each sub district has facilities and infrastructures with five dedicated staffs to handle the area's mobile applications account. The system enables citizen's reports and complaints that have been submitted through mobile application being tracked in every stage of reporting stage from submission, procession, until finalization (problem solved). Management of m-government were originally handled by municipals' governance unit (Tata Pemerintah), then it was delegated to implementation unit (Tata Laksana) who now conducts coaching, training, information sharing, and other coordination activities. This unit track all citizen reports and complaints for check and balance mechanism. In collaboration with the ministry of communication and telecommunication, all municipals have upgraded their system to a new one called CRM (Citizen Relationship Management). This new system integrates all sources of citizen reporting i.e. Facebook, Twitter, Governor's cellular number, Call Center 112, Qlue application, and digital klipping into one gate channel. The ministry of communication and informatics are still conducting ongoing improvement to the system. Types of report that the municipals received vary from traffic jams, illegal parking and construction or building to barking dogs [6].

The government provides budget for ICT related operational cost such as provision of mobile phone and monthly billing allowance to support m-government down to head of neighborhood level. The latter is the focal point that represent their communities to interact with sub district office for community level public service. Sub district or urban village officials together with experts from the ministry of communication and informatics have socialized the use of ICT to neighborhood association (Rukun Tetangga/RT) and hamlet association (Rukun Warga/RW) to encourage them to use mobile apps (Qlue applications) for reporting. However, the use of mobile apps among RT and RW leaders remains low (less than 5\%). Citizens in Central Jakarta prefer to contact the urban village by telephone or texting via whatssapp. The low use of mobile apps among RT and RW leaders are possibly due to their age. In central of Jakarta, head of RT and RW are usually senior citizen who have retired from their job, age around 50 years or older and therefore have time to take charge as the neighbourhood or hamlet association leader to fill their spare time to gather and socialize in the community rather than using social media. They are not accustomed to the fast changing technology for communication. To adapt to these conditions, the government uses conventional communication method, for example sending printed letters or announcement, conducting town hall meeting or communication in person to promote and enforce regulations. Youth at the neighborhood level are actively involved in the community through Karang Taruna (neighbourhood level informal association for youth), but they have limited (if not at all) influence to their communities because Indonesian culture pays more respect to senior member in the society. The government should provide trainings in a regular basis to encourage the use of ICT for reporting to tackle these challenges.

\section{CONCLUSION}

The provincial government of Jakarta has targeted the capital city of Jakarta to be the center of knowledge, technology, and intellectualism as stated in its 2013-2017 mid term plan. In addition, the provincial government of Jakarta has targeted to achieve 'Smart City' standard. In line with its vision and mission, the city applies information, communication, and technology to build 1) e-government to enhance good governance and transparency and 2) m-government to achieve the smart city standard of smart, efficient and competitive. 
Web based e-government has been developed extensively across all level of provincial government units, horizontally and vertically. In the period of 2013 to 2017, the provincial government expanded e-government service across many areas of provincial management and administration: eplanning, e-budgeting, e-procurement, e-pegawai and ekinerja.

The m-government that focuses on lower level of government such as municipals, district and sub district is progressing. Jakarta has planned to build infrastructure for telecommunication, electricity, and energy and modernize the province security monitoring mechanism with CCTV in highly risk areas. Having observed insights and perspectives from various actors, their interaction and institutional factors in regards to ICT based governance and public administration, we found that citizens of Jakarta, especially the youth, are critical towards the government's public services delivery. Efforts to achieve the city's competitiveness that is conducive for business can be focused on democracy and peacebuilding. To educate citizen to respect democracy and peacebuilding, government should address citizen down to urban village level, adjusting its approach when interacting with citizen in accordance to each village's unique characteristic such as demography, by paying special attention to the age group factor. The senior age citizens, who mostly have entered retirement, prefer direct communication in person, in a gathering and meetings rather than virtual interaction using mobile application or social media. In regards conducive community condition, young age group also prefer real life social gathering, in which local wisdom of musyawarah or mahbudiyah are still respected to keep a peaceful democracy. Traditional printed news and TV broadcast are still considered effective as means to promote democracy and peace. To increase citizen's participation in terms of ICT based interaction, the government has to ensure its mobile apps will satisfy the citizen's sense of self identity and self fulfilment, that it will be beneficial and meet the citizen's interest. The ministry of communication and informatics contributed to mgovernment by helping to integrate various sources of citizen reporting (Facebook, Twitter, Governor cellular number for SMS, Call Center 112, Qlue application and digital clipping) into one reporting channel called Citizen Relationship Management. The provincial governmentof Java, Bali, Papua, Maluku, Nusa Tenggara, and Kalimantan Islands are expected to upscale their ICT based public services through mobile based applications. There is a need for national government regulation to manage the fast growing ICT based governance, especially the m-government, as an extension of egovernment.

While implementation of e-government depends on the provincial leadership commitment as it is intended as internal accountability mechanism, implementation of m-government is more complex because it involves citizen's attitude. Citizens in Jakarta comes from multicultural background, different social classes and demographic characteristics, all of which contribute to their unique attitude and preference toward ICT based interaction with government. As the m-government has not been fully used by citizen, the future trend in citizen and government interaction is still dominated by traditional method such as verbal communication through meeting in person or telephone call. Further research is required to understand factors that influence citizen's participation in $\mathrm{m}$ government.

\section{REFERENCES}

[1] APJII (2014). Profil Pengguna Internet Indonesia 2014. Asosiasi Penyelenggara Jasa Internet Indonesia. Retrieved from https://apjii.or.id/content/read/39/27/PROFIL-PENGGUNAINTERNET-INDONESIA-2014

[2] Carina, Jessi (2017, Agustus 31). Djarot Sebut PNS DKI Bisa Dipecat Jika Lambat Tangani Laporan di Qlue. Kompas, Retrieved from http://megapolitan.kompas.com/read/2017/08/31/12163201/djarot-sebutpns-dki-bisa-dipecat-jika-lambat-tangani-laporan-di-qlue

[3] Gil-Garcia, J.R., Helbig, N. \& Ojo, A. (2014) "Being smart: Emerging technologies and innovation in the public sector. Government Information Quarterly", 31, $11-$ I8 https://pdfs.semanticscholar.org/7bf5/1374e59a87e26e264192b52ad145 c6365576.pdf

[4] Hambali (n.d.), Implementasi Mobile Government Services. Yudharta, Retrieved from http://jurnal.yudharta.ac.id/wpcontent/uploads/2014/08/IMPLEMENTASI-MOBILEGOVERNMENT-SERVICES-Studi-Kasus-di-Australia-danIndonesia.pdf

[5] Hoesin, H. et al. (2008). Penilaian Situs Pemerintah Daerah di Provinsi DKI Jakarta, Bengkulu, Jambi, dan Bangka Belitung. UPN "Veteran" Yogyakarta. Retrieved from http://jurnal.yudharta.ac.id/wpcontent/uploads/2014/08/IMPLEMENTASI-MOBILEGOVERNMENT-SERVICES-Studi-Kasus-di-Australia-danIndonesia.pdf

[6] Maranny, E. A. (2011). Stage Maturity Model of m-Government (SMM $\mathrm{m}$-Gov): Improving e-Government performance by utilizing $\mathrm{m}$ Government features(Master's thesis, University of Twente). http://essay.utwente.nl/62691/1/EAMaranny_Thesis_SMM_m-Gov.pdf

[7] OECD/International Telecommunication Union (2011), M-Government: Mobile Technologies for Responsive Governments and Connected Societies, OECD Publishing. http://unpan1.un.org/intradoc/groups/public/documents/undpadm/unpan047499.pdf

[8] Redaksi (2016, June 1). Dinamika Penerapan "e-Government" di Indonesia. Universitas Indonesia. Retrieved from http://www.ui.ac.id/berita/dinamika-penerapan-e-government-diindonesia.html

[9] The Daily Oktagon (2016, November 10). Apa Kabar Penerapan Smart City di Indonesia? The Daily Oktagon. Retrieved from https://daily.oktagon.co.id/apa-kabar-penerapan-smart-city-di-indonesia/

[10] White, B., \& Naafs, S. (2012). Generasi antara: refleksi tentang studi pemuda Indonesia. Jurnal Studi Pemuda, 1(2), 89-106.

[11] Winarko, Willy (2019, June 9). Three Indonesian smart cities to look up to. The Jakarta Post. Retrieved from http://www.thejakartapost.com/life/2017/06/09/three-indonesian-smartcities-to-look-up-to.html

[12] Winarko, Andi D. (2017, Agustus 31). 13 Kelurahan di Jakarta Abaikan Ratusan Aduan Warga di Qlue. Kompas. Retrieved from http://megapolitan.kompas.com/read/2017/08/31/15063691/13kelurahan-di-jakarta-abaikan-ratusan-aduan-warga-di-qlue

[13] Zubizarreta, I., Seravalli, A., Arrizabalaga, S. (2016)“Smart City Concept: What It Is and What It Should Be.” Journal of Urban Planning and Development, Volume 142, Issue 1, http://ascelibrary.org/doi/abs/10.1061/(ASCE)UP.1943-5444.0000282 